In cooperation with the Wisconsin Department of Natural Resources

\title{
Characterizing the Size Distribution of Particles in Urban Stormwater by Use of Fixed-Point Sample-Collection Methods
}
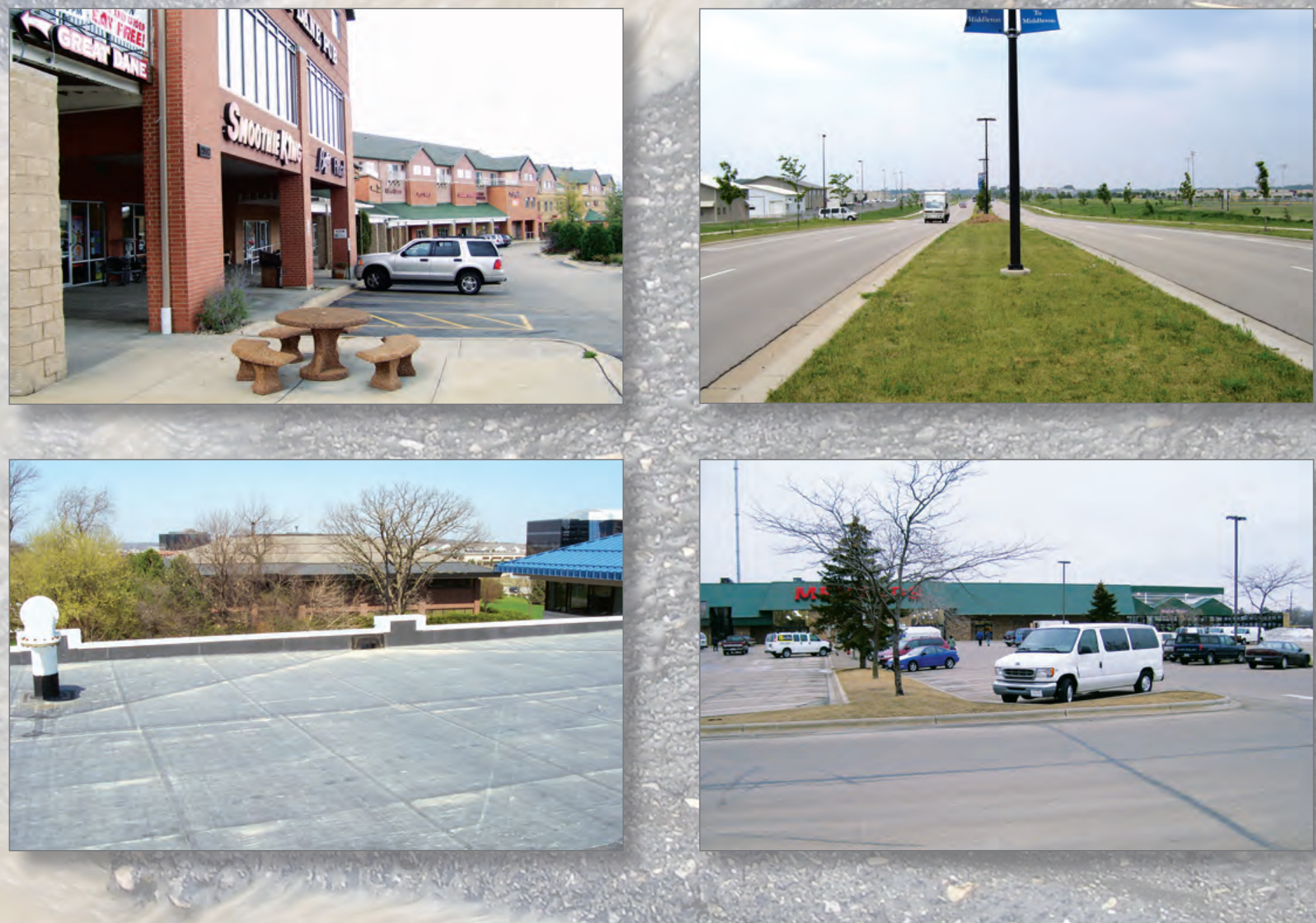

Open-File Report 2011-1052 



\section{Characterizing the Size Distribution of Particles in Urban Stormwater by Use of Fixed-Point Sample-Collection Methods}

By William R. Selbig and Roger T. Bannerman

In cooperation with the Wisconsin Department of Natural Resources

Open-File Report 2011-1052 


\title{
U.S. Department of the Interior \\ KEN SALAZAR, Secretary \\ U.S. Geological Survey \\ Marcia K. McNutt, Director
}

\section{U.S. Geological Survey, Reston, Virginia: 2011}

\author{
For more information on the USGS — the Federal source for science about the Earth, its natural and living resources, \\ natural hazards, and the environment, visit http://www.usgs.gov or call 1-888-ASK-USGS \\ For an overview of USGS information products, including maps, imagery, and publications, \\ visit http://www.usgs.gov/pubprod \\ To order this and other USGS information products, visit http://store.usgs.gov
}

\begin{abstract}
Any use of trade, product, or firm names is for descriptive purposes only and does not imply endorsement by the U.S. Government.

Although this report is in the public domain, permission must be secured from the individual copyright owners to reproduce any copyrighted materials contained within this report.
\end{abstract}

Suggested citation:

Selbig, W.R., and Bannerman, R.T., 2011, Characterizing the size distribution of particles in urban stormwater by use of fixed-point sample-collection methods: U.S. Geological Survey Open-File Report 2011-1052, 14 p.. 


\section{Contents}

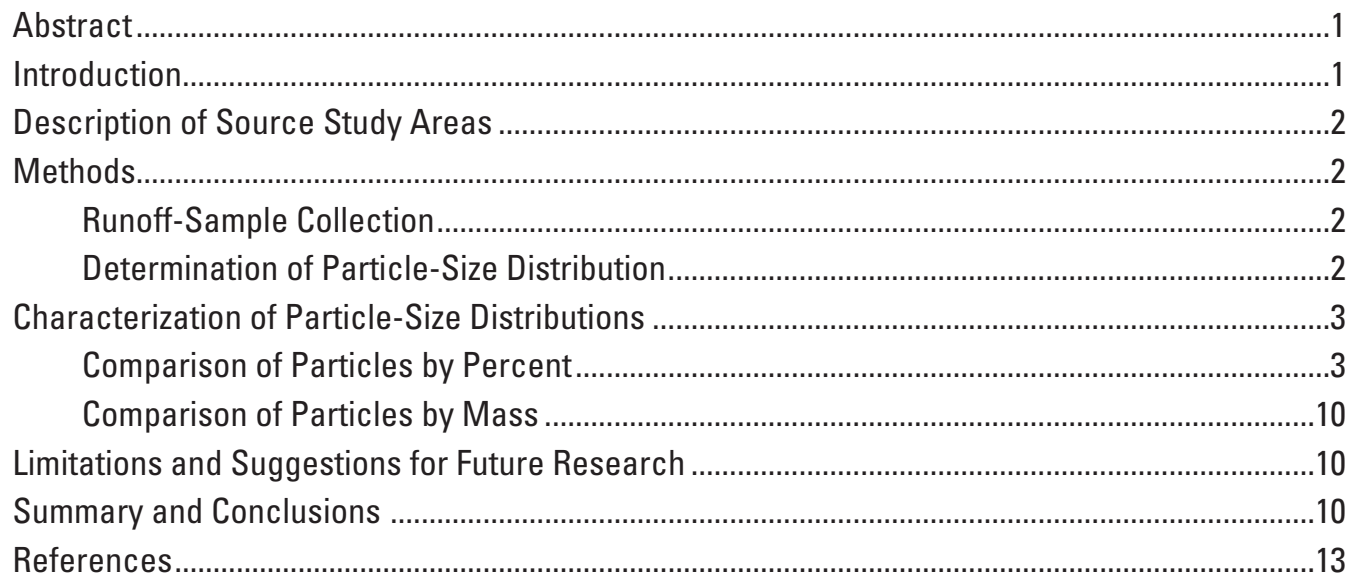

\section{Figures}

1. Distribution of particle size for individual samples and resulting median value, Madison, Wis., study area. $A$, Parking lot. $B$, Institutional roof.

$C$, Collector street. $D$, Feeder street. $E$, Arterial street. F, Mixed-use area.........................5

2. Comparison of the distribution of particles measured from six source areas as part of the Madison, Wis., study to that reported by Driscoll (1986) ...................9

3. Median percent contribution of total mass for particles in sediment from stormwater runoff, Madison, Wis., study area. $A$, Greater than 32 micrometers. $B$, Less than 32 micrometers

\section{Tables}

1. Source areas and land use sampled for distribution of particles in urban stormwater

2. Summary statistics of particle size distributions represented as percent finer than the corresponding particle size ......................................................................

3. Comparison of median particle size in stormwater runoff from previous studies..............8

4. Comparison of similarity or difference in the percentage of sand in samples from six source areas in Madison, Wis. using Dunn's procedure ..................9

5. Summary statistics of particle-size distributions, Madison, Wis., study area, represented as a concentration. 


\section{Conversion Factors}

\begin{tabular}{lll}
\hline \multicolumn{1}{c}{ Multiply } & \multicolumn{1}{c}{ By } & \multicolumn{1}{c}{ To obtain } \\
\hline inch (in.) & \multicolumn{1}{c}{ Length } \\
foot $(\mathrm{ft})$ & 2.54 & \multicolumn{1}{c}{ centimeter $(\mathrm{cm})$} \\
micrometer $(\mu \mathrm{m})$ & 0.3048 & meter $(\mathrm{m})$ \\
\hline \multicolumn{3}{c}{ Mass } \\
\hline gram $(\mathrm{g})$ & 0.00003937 & inch (in) \\
\hline \multicolumn{2}{c}{ Volume } \\
\hline liter $(\mathrm{L})$ & 0.03527 & ounce, avoirdupois $(\mathrm{oz})$ \\
milliliter $(\mathrm{mL})$ & 0.2642 & gallon (gal) \\
\hline
\end{tabular}

Temperature in degrees Celsius $\left({ }^{\circ} \mathrm{C}\right)$ may be converted to degrees Fahrenheit $\left({ }^{\circ} \mathrm{F}\right)$ as follows:

${ }^{\circ} \mathrm{F}=\left(1.8 \times{ }^{\circ} \mathrm{C}\right)+32$

Concentrations of sediment are given in milligrams per liter $(\mathrm{mg} / \mathrm{L})$. 


\title{
Characterizing the Size Distribution of Particles in Urban Stormwater by Use of Fixed-Point Sample-Collection Methods
}

\author{
By William R. Selbig and Roger T. Bannerman
}

\begin{abstract}
The distribution of particles in runoff was characterized from six types of urban source areas (parking lot, feeder street, collector street, arterial street, rooftop, and mixed use) around Madison, Wis. The lowest median particle sizes were found at the mixed-use and parking-lot study areas (42 and 54 micrometers $(\mu \mathrm{m})$, respectively), followed by the collector street $(70 \mu \mathrm{m})$. Similar median particle sizes of approximately $95 \mu \mathrm{m}$ were found for both the arterial street and institutional roof study areas. The largest median particle size, nearly $200 \mu \mathrm{m}$, was measured in feeder street samples. Variability in median particle size and distribution was considerable between source areas. Variability was also evident in comparisons with similar source area types from previous studies. Much of the variability can be attributed to use of different analytical techniques, sample-collection methods, and reporting between researchers. Results from this study further document the difficulty of deriving a single particlesize distribution that is representative of stormwater runoff generated from more than one source area.
\end{abstract}

\section{Introduction}

Sediments in stormwater runoff from urban areas, and metals and hydrocarbons associated with these sediments, are a substantial source of contamination to receiving waters and associated toxic effects to aquatic organisms. Water-quality data from 10 Wisconsin storm sewers showed that 74 percent of the total metal load was associated with particulate matter, whereas 26 percent of the metal load was in the dissolved form (Bannerman and others, 1996). In addition, greater than 86 percent of all polycyclic aromatic hydrocarbons detected in samples from a municipal maintenance garage and storage facility in Milwaukee were particulate associated, whereas less than 14 percent were in dissolved form (Corsi and others, 1999). These data suggest that treatment options for urban stormwater should include specific plans to target sediment as the primary source of contamination to receiving streams. Watershed managers in urban areas need information to help choose the most effective means to reduce sedimentassociated contaminants in urban runoff. Numerous structural best management practices (BMPs) provide some level of sediment control and are readily available. However, because many of these devices rely on settling of solids, their effectiveness is largely dependent on the range of particle sizes in stormwater runoff. Variation of particle sizes can be attributed to a combination of site conditions such as vehicular activity, soil type, overhead tree canopy, wind patterns, and rainfallrunoff characteristics. In order to select the most appropriate BMP for sediment control, characterization of particles found in stormwater runoff becomes increasingly important. Data are currently lacking in this area. In Wisconsin, many control devices are selected and sized according to a generalized particle-size distribution from historical datasets collected as part of the Nationwide Urban Runoff Program (NURP) (U.S. Environmental Protection Agency, 1982). Few particlesize data are available for specific source areas and land uses.

In 2005, the U.S. Geological Survey (USGS), in cooperation with the Wisconsin Department of Natural Resources (WDNR) and in collaboration with the Root River Municipal Stormwater Permit Group, began a study to help municipalities reduce the uncertainty in their stormwater-management planning by improving the characterization of particle-size distributions in urban stormwater runoff from specific sourcearea and land-use categories. This information can then be used to assist watershed managers and engineers in designing the most appropriate control devices for reduction of sediment in urban stormwater runoff. The primary objective of this report is to summarize particle-size distributions collected from six urban source areas in or near Madison, Wis., during the study and to compare these data to distributions from other published studies. 


\section{Description of Source Study Areas}

This study characterized distribution of particles in stormwater runoff from six types of urban source areas (table1). Selection was based on the prevalence of the specific types of source areas within urban watersheds. Data from source area types with multiple sampling sites were synthesized to represent their respective source area type. For example, data from three different commercial parking lots were compiled into a single dataset representing all parking lots. Street type was categorized by traffic volume as a feeder, collector, or arterial. A summary of the geographic setting and physical description for each study area can be found in Selbig and Bannerman (2009).

Table 1. Source areas and land use sampled for distribution of particles in urban stormwater.

\begin{tabular}{llc}
\hline \multicolumn{1}{c}{ Source area } & \multicolumn{1}{c}{ Land use } & Number of sites \\
\hline Parking lot & Commercial & 3 \\
Streets & Residential, Commercial & 3 \\
Rooftop & Institutional & 1 \\
Mixed Use & Commercial (strip mall) & 1 \\
\hline
\end{tabular}

\section{Methods}

\section{Runoff-Sample Collection}

An automated monitoring station was used to measure flow and collect samples near the basin outlet of each source area or land use monitored in this study. Each monitoring station was equipped with automated stormwater-quality samplers and instruments to measure discharge. Measurement, control, and storage of data were done by way of electronic dataloggers. Precipitation data were collected by use of a tipping-bucket rain gage calibrated to $0.01 \mathrm{in}$. Discharge was measured by use of a probe with two different sensor systems mounted to the bottom of each pipe. Each probe contained a pressure transducer to measure water level and a pair of ultrasonic transducers to measure velocity. A fifth-order polynomial was used to relate water level to cross-sectional area for each pipe configuration. Instantaneous pipe discharge was then computed by multiplying the cross-sectional area of the pipe by the associated mean velocity. Storm-runoff volumes were computed by summing the 1-minute-interval instantaneous discharge during the sampled storm.

Sample collection was activated by a rise in water level in the pipe during a precipitation event. Once the water-level threshold was exceeded, typically a depth of $0.15 \mathrm{ft}$ from the pipe floor, the volume of water passing the station was measured and accumulated at 1-minute increments until a volumetric threshold was reached. At that point, the sampler collected a discrete water sample and the volumetric counter was reset. The process was repeated until the water level receded below the threshold. Samples representing less than 80 percent of the storm-hydrograph were precluded from data analyses. The intake nozzle of the sampler orifice was fixed approximately $0.5 \mathrm{in}$. above the pipe floor. The location of the fixed-point sample intake was chosen to accommodate a range of flow conditions. Subsamples, $1 \mathrm{~L}$ in volume, were transferred through the sample tubing into a $10-\mathrm{L}$ glass jar. These flow-weighted samples were collected and composited into a single water sample, then split and processed for analysis. Because each discrete sample was composited into a single event sample, the resulting concentrations and distributions represent the event mean.

A Teflon churn splitter was used to composite and split samples into smaller, 4-L plastic containers for particlesize distribution analysis. Processed samples were kept in a refrigerator at $4^{\circ} \mathrm{C}$ until delivered to the analytical laboratory, usually within 48 hours after runoff cessation. Because each discrete sample was composited into a single event sample, the resulting distributions represent the event mean distribution. Samples were analyzed at the Wisconsin State Laboratory of Hygiene (WSLH), in Madison.

\section{Determination of Particle-Size Distribution}

Upon receipt of the sample, WSLH would determine the total mass after correcting for the weight of the container. It was assumed that sample density approximated that of pure water so the units of mass could be directly related to units of volume; for example, $1 \mathrm{~mL}$ of water is equal to $1 \mathrm{~g}$. Water density corrections are required when the suspended-sediment concentration exceeds $8,000 \mathrm{mg} / \mathrm{L}$ (ASTM International, 2009). None of the samples evaluated as part of this study approached that magnitude of solids concentration. The sample was then wet sieved through a series of stacked nylonmesh sieves, which separated the solid-phase material from the sample into five separate particle-size fractions: $\geq 500$, $250-<500,125-<250,63-<125$, and $32-<63 \mu \mathrm{m}$. Material retained on each sieve was transferred into a clean, tared, heat-tolerant container and dried overnight at 105 degrees $\mathrm{C}$. Transfer of material from each sieve into the container was done by use of deionized water. The mass of dried material recovered from each sieve was measured and recorded. This process was repeated for each of the five size fractions. The total mass for each fraction was then divided by the volume of the original sample to achieve a mass concentration. Particles less than $32 \mu \mathrm{m}$ were quantified by use of a Coulter counter (Beckman Coulter, 2010) into five separate particle-size fractions: $14-<32,8-<14,5-<8,2-<5$, and $<2 \mu \mathrm{m}$. 


\section{Characterization of Particle-Size Distributions}

\section{Comparison of Particles by Percent}

The distribution of particles in urban stormwater is commonly reported in terms of the percentage of all particles in a water sample that are finer (by mass) than a specific particle size. Table 2 details summary statistics for each particle-size fraction measured in sampled precipitation events at the eight study locations. Data from each of the three parking lots were synthesized to represent a single parking-lot source area. Tests for normality by use of the Shapiro-Wilk test (Helsel and Hirsch, 1992) showed that most of the data used to create table 2 did not fit a normal or log-normal distribution, indicating skewness and variability. The degree of variability is most apparent in figures $1 A-1 F$, which illustrate particle-size distributions from all samples within each source area that were analyzed as part of this study. Given the degree of variability and lack of normality in the data, the median distribution was chosen as the most appropriate representation of particles from each study area because the median is a better representation of the population center in highly skewed datasets than the mean (Ott and Longnecker, 2001). A commonly reported metric for the distribution of particles in stormwater is the median particle size $\left(\mathrm{d}_{50}\right)$. Because all particles measured as part of this study were categorized into separate size fractions - for example, the 63- through $125-\mu \mathrm{m}$ fraction-the median particle size was estimated by using figures $1 A-1 F$. Mixed-use and parking-lot study areas had the lowest median values (42 and $54 \mu \mathrm{m}$, respectively), followed by the collector street $(70 \mu \mathrm{m})$. Both the arterial street and institutional roof study areas had similar median particle sizes of approximately $95 \mu \mathrm{m}$. Finally, the feeder street study area showed the largest median particle size of nearly $200 \mu \mathrm{m}$.

Median particle-size distributions from each source area were compared to data from other studies that characterized particle sizes in urban stormwater (table 3). The majority of these studies focused on particles entrained in runoff originating from streets, particularly highways. A wide range in median particle size was found both amongst and between urban source areas and land uses. The $\mathrm{d}_{50}$ for highways ranged from 570 to less than $3 \mu \mathrm{m}$. On the basis of the estimates from figures $1 A-1 F$, median particle size from the parking lot, arterial street, and mixed-use study areas $(54,95$, and $42 \mu \mathrm{m}$, respectively) compared favorably to values from the literature presented in table 3. Several studies, in addition to those listed in table 3 , reported the distribution of particles in terms other than a median particle size. Results of these studies suggest substantial variability in data can inhibit the development of a single particle-size distribution that is representative of stormwater runoff generated from a single source area or land use. Numerous studies reported the majority of particles in stormwater trended toward the fine end of the distribution range, with approximately 80 percent less than $44 \mu \mathrm{m}$ (Kobringer, 1984; Driscoll, 1986; Ball and Abustan, 1995). Yet, other studies suggest a coarser distribution, where the majority of particles were sand $(>63 \mu \mathrm{m})$ (Sansalone and others, 1998; Selbig and Bannerman, 2007; Kim and Sansalone, 2008, Horwatich and others, in press). Figure 2 illustrates median particle-size distributions derived from samples collected as part of this study. Although median particle sizes vary between source areas, they are larger than those reported from similar studies done in the mid-1980s.

By use of the Kruskal-Wallis test (Helsel and Hirsch, 1992), all samples collected as part of this study were evaluated to determine whether the percentage of sand within each source area came from the same general population. If the test affirmed the null hypothesis that all distributions were from the same general population, then a single distribution could be assumed for all source areas. Results of the test rejected the null hypothesis, indicating at least one of the source areas had a significantly different percentage of sand (5-percent significance level) than the others. An additional test was done by means of Dunn's procedure (Dunn, 1964) on multiple pairwise comparisons to identify where significant differences in median particle-size distribution between source areas occur and to distinguish those differences by sorting each source area into similar groups. Results of the test are summarized in table 4. Three distinct groups are presented in table 4 that identify, qualitatively, if a difference in the percent sand from sample populations within a source area is different than other source areas. Overlap between groups depicts no difference. For example, the collector street was not statistically different than any other source area (table 4). The parking lot was not statistically different than mixed use, collector street, or arterial street study areas but was statistically different than the institutional roof and feeder street (table 4). Results of the Kruskal-Wallis test and Dunn's procedure suggest no single particle-size distribution can be applied to all source areas.

Researchers often employ different analytical techniques, such as laser diffraction, optical sensors, settling rates, or wet/ dry sieving when determining the distribution of particles in stormwater (table 3). Much of the inconsistency can be attributed to the lack of analytical equipment capable of covering the wide range of particle sizes found in urban stormwater. Therefore, each method has the propensity to produce methodspecific results. Similarly, selection of the particle-size fraction or range of fractions (upper and lower) used by each researcher to characterize the distribution is inconsistent. Furthermore, sample-collection methods vary widely. As a result, much of the variability evident in table 3 may be attributed to differences in analytical method or sample-collection method, or both. 
Table 2. Summary statistics of particle size distributions represented as percent finer than the corresponding particle size. All values, with the exception of the number of observations, are expressed as a percent.

[No., number; <, less than]

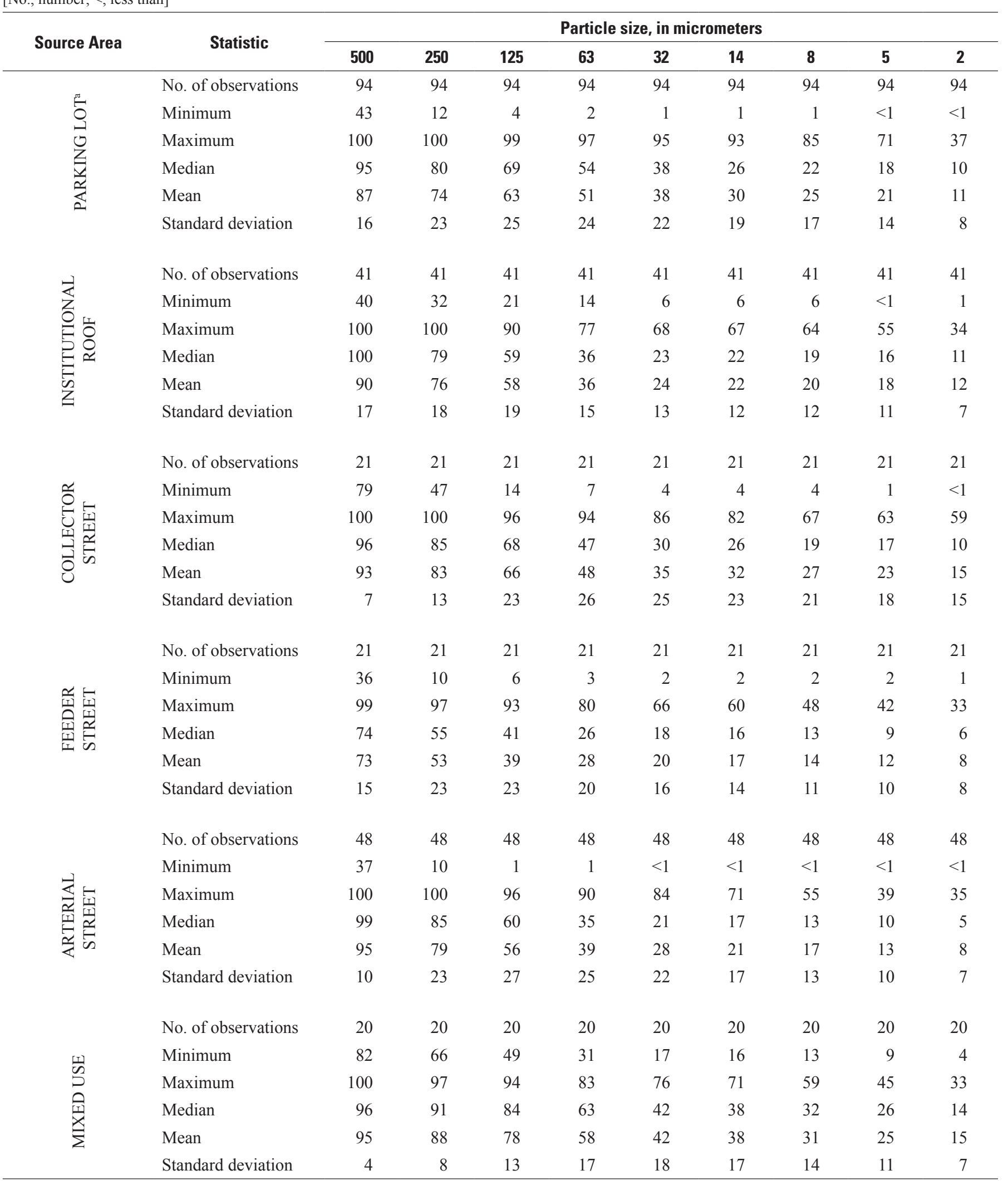

${ }^{\text {a }}$ compilation of all three parking lot study sites 

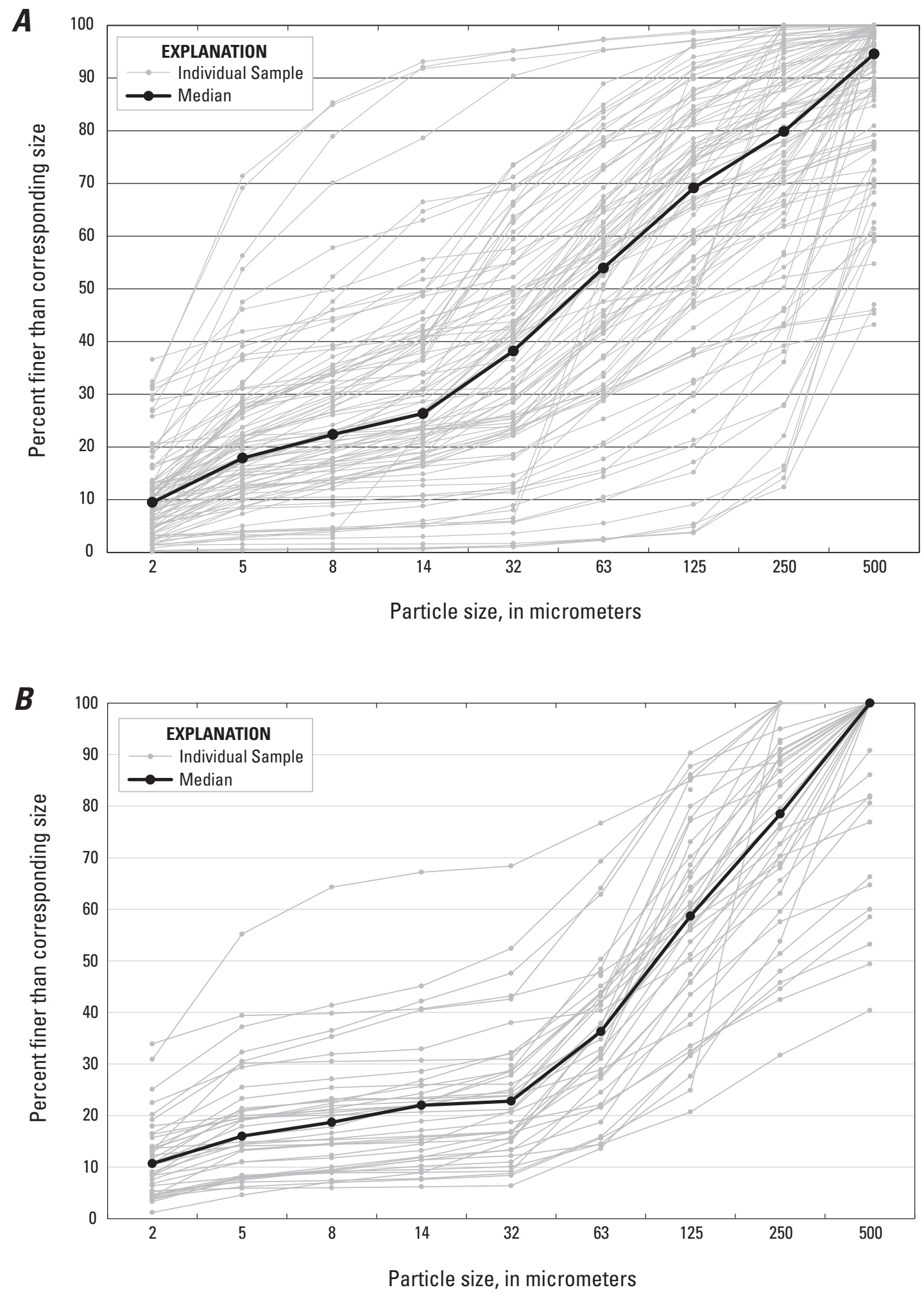

Figure 1. Distribution of particle size for individual samples and resulting median value, Madison, Wis., study area. $A$, Parking lot. $B$, Institutional roof. $C$, Collector street. $D$, Feeder street. $E$, Arterial street. $F$, Mixed-use area. 

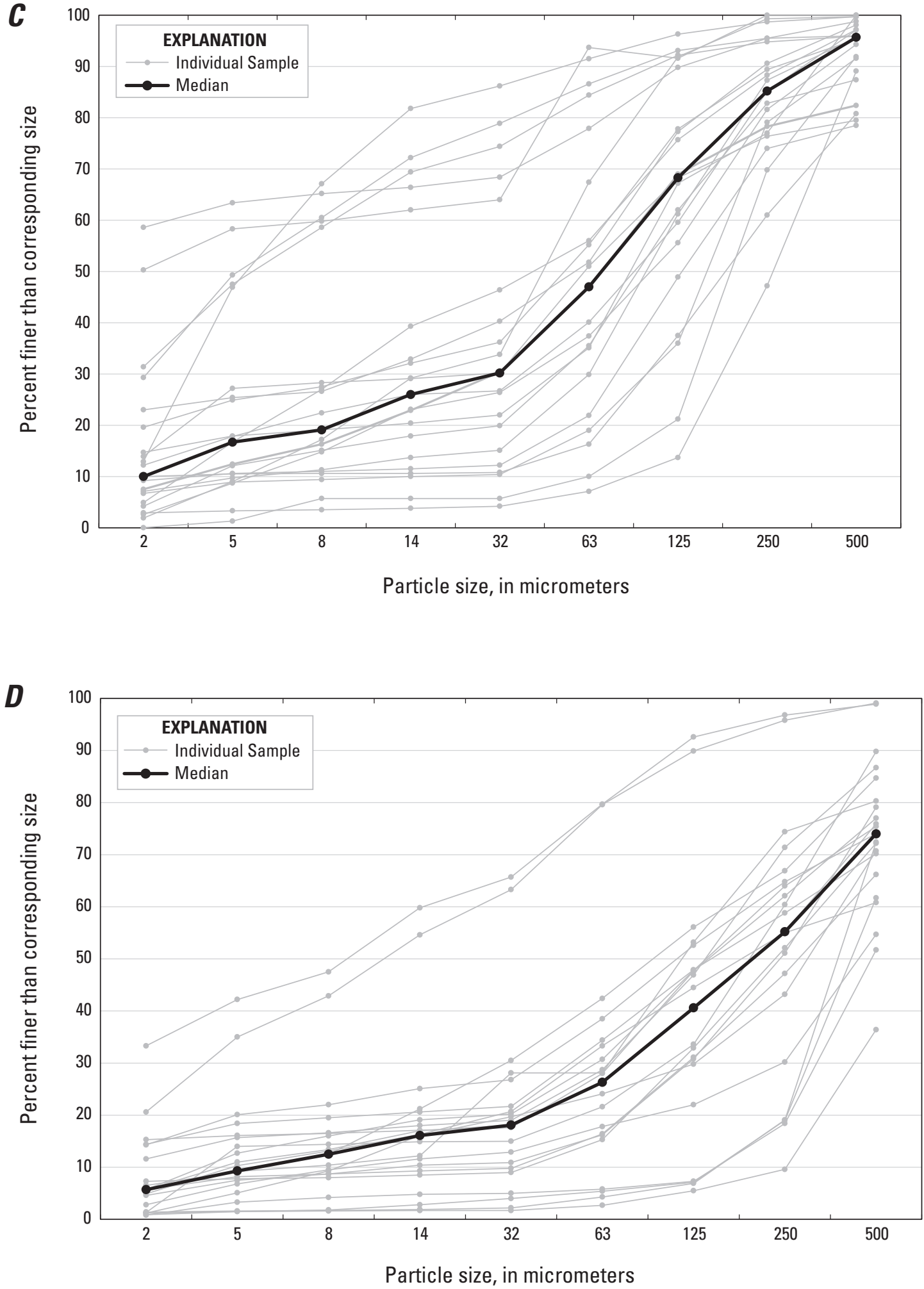

Figure 1. Continued. 

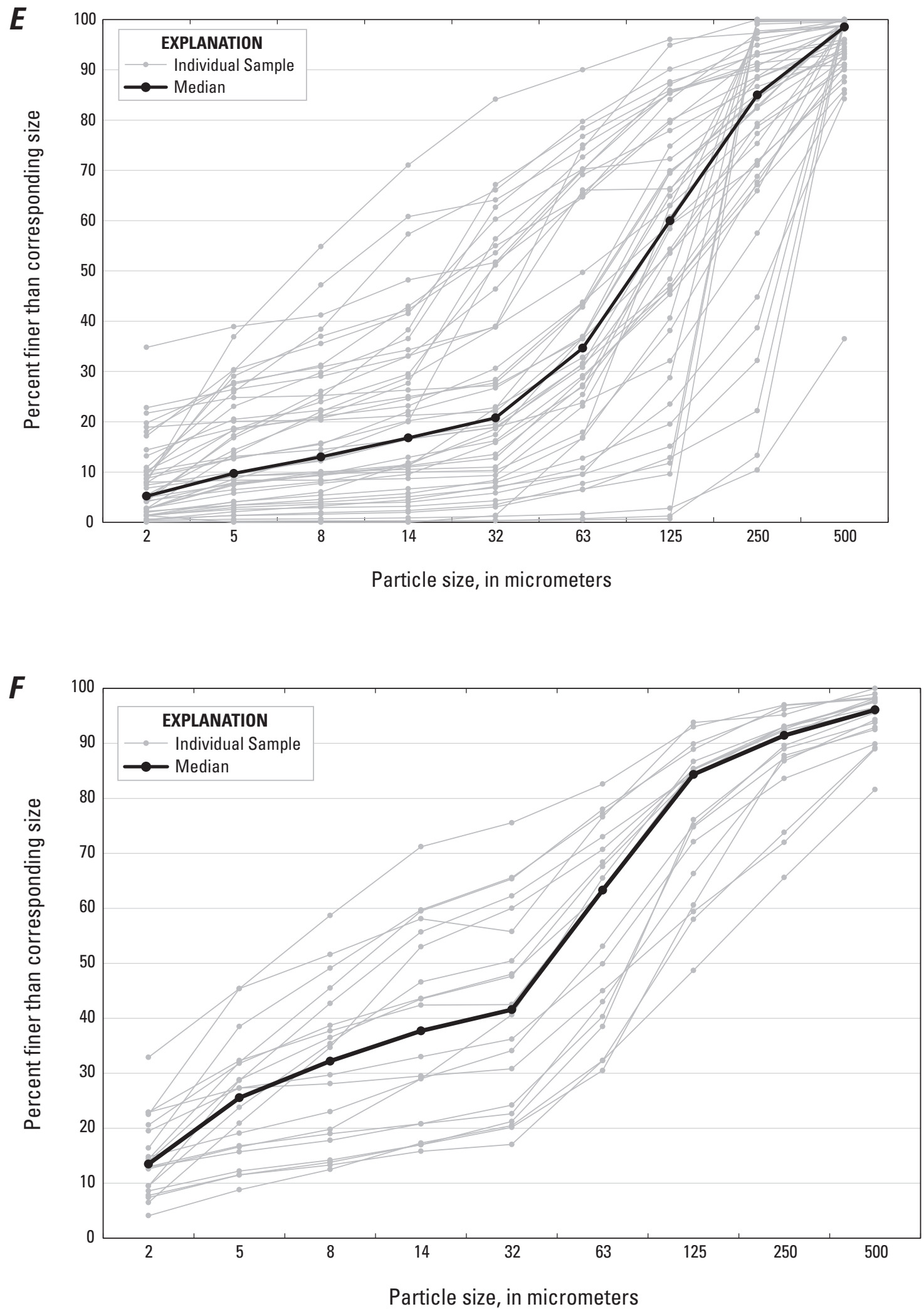

Figure 1. Continued. 
Table 3. Comparison of median particle size in stormwater runoff from previous studies.

[A, autosampler; G, grab; ST, settling tank; B, bedload sampler]

\begin{tabular}{|c|c|c|c|c|c|}
\hline $\begin{array}{l}\text { Source area } \\
\text { or land use }\end{array}$ & $\begin{array}{l}\text { Number } \\
\text { of samples }\end{array}$ & $\begin{array}{l}\text { Sample } \\
\text { method }\end{array}$ & Analytical method & d50( $\mu \mathrm{m})$ & Source \\
\hline Highways & 13 & A & Particle analyzer & 570 & Sansalone and others (1998) \\
\hline Highways & 172 & G & Particle analyzer & $2.7-7.1$ & Li and others (2006) \\
\hline Highways & 14 & A & Visual accumulation tube & 340 & Horwatich and others (2010) \\
\hline Highways & 8 & A & Particle analyzer & 15.9 & Andral and others (1999) \\
\hline Highways & 7 & A & Particle analyzer & $4-6$ & Westerlund and Viklander (2006) \\
\hline Collector streets & 21 & A & $\begin{array}{l}\text { Wet sieve }(>32 \mu \mathrm{m}) \\
\text { particle analyzer }(<23 \mu \mathrm{m})\end{array}$ & $70^{\mathrm{b}}$ & Present study \\
\hline Feeder streets & 21 & A & $\begin{array}{l}\text { Wet sieve }(>32 \mu \mathrm{m}) \\
\text { particle analyzer }(<23 \mu \mathrm{m})\end{array}$ & $200^{\mathrm{b}}$ & Present study \\
\hline Parking lot & 18 & A & Particle analyzer & 46 & Fowler and others (2009) \\
\hline Parking lot & 94 & A & $\begin{array}{l}\text { Wet sieve }(>32 \mu \mathrm{m}) \\
\text { particle analyzer }(<23 \mu \mathrm{m})\end{array}$ & $54^{\mathrm{b}}$ & Present study \\
\hline Institutional roof & 41 & A & $\begin{array}{l}\text { Wet sieve }(>32 \mu \mathrm{m}) \\
\text { particle analyzer }(<23 \mu \mathrm{m})\end{array}$ & $95^{\mathrm{b}}$ & Present study \\
\hline Mixed use & 4 & A & Particle analyzer & 31 & Anta and others (2006) \\
\hline
\end{tabular}

${ }^{\mathrm{b}}$ estimate 


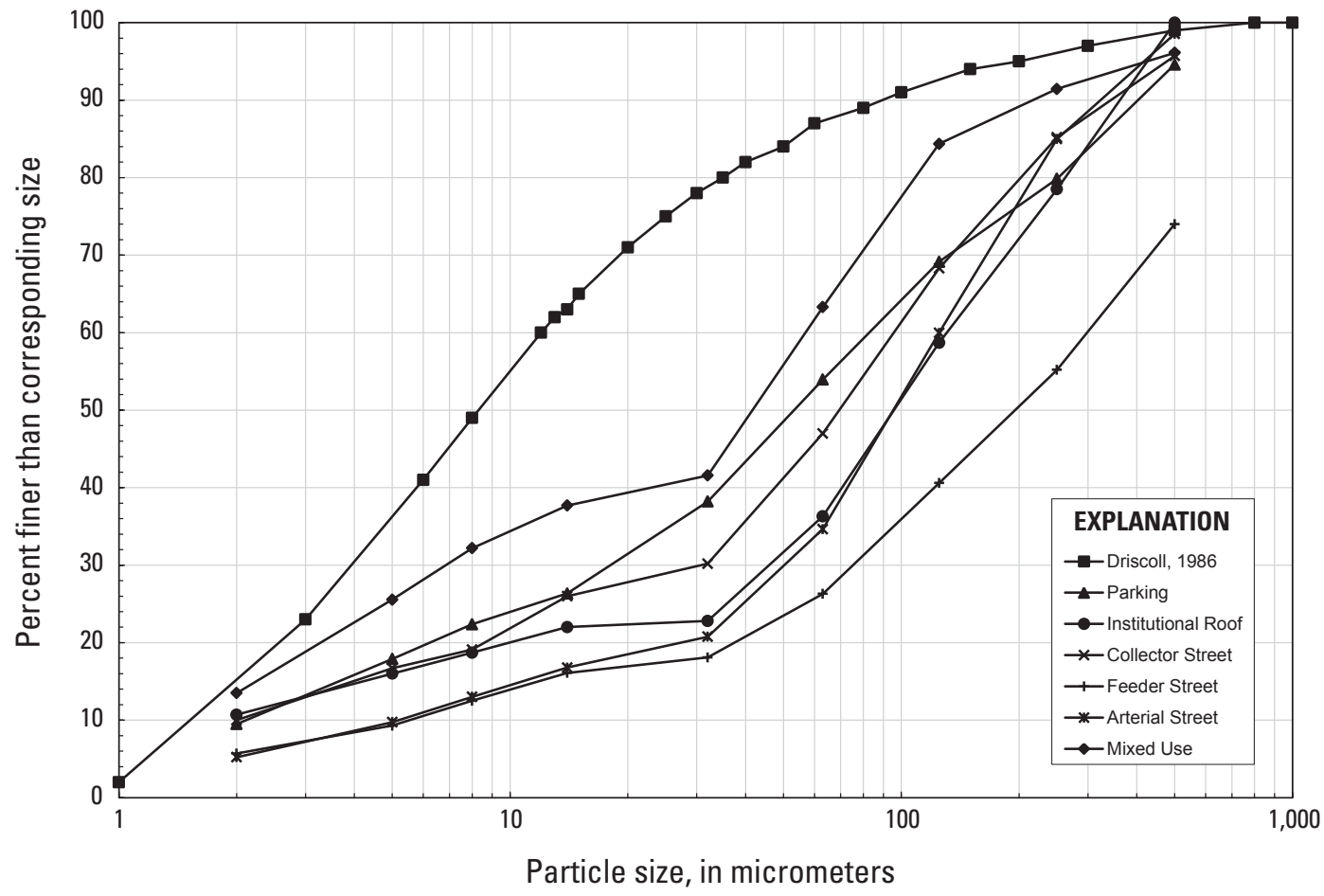

Figure 2. Comparison of the distribution of particles measured from six source areas as part of the Madison, Wis., study to that reported by Driscoll (1986).

Table 4. Comparison of similarity or difference in the percentage of sand in samples from six source areas in Madison, Wis. using Dunn's procedure.

\begin{tabular}{lcccccc}
\hline \multicolumn{1}{c}{ Source Area } & Observations & Sum of ranks & Mean of ranks & & Groups & \\
\hline Mixed Use & 20 & 1614 & 81 & A & & \\
Parking Lots & 94 & 9613 & 102 & A & B & \\
Collector Streets & 21 & 2366 & 113 & A & B & C \\
Arterial Streets & 48 & 6586 & 137 & & B & C \\
Institutional Roof & 41 & 6271 & 153 & & & C \\
Feeder Streets & 21 & 3685 & 175 & & & C \\
\hline
\end{tabular}




\section{Comparison of Particles by Mass}

Figures $3 A$ and $3 B$ illustrate the median values of percent total mass contributed by each particle-size fraction from each study area. The values in figures $3 A$ and $3 B$ have been scaled to equal 100 percent. Particles less than $32 \mu \mathrm{m}$ in figure $3 A$ were further subdivided into smaller particle-size fractions for greater resolution (fig. 3B). Feeder street samples had the greatest percentage of total mass from sand-size particles $(>63 \mu \mathrm{m})$ compared to samples from other source areas, and nearly 30 percent came from particles greater than $500 \mu \mathrm{m}$. Less than 10 percent was attributed to that fraction for all other source areas. The majority of particle mass in four out of the six source areas was dominated by silt and clay particles that are less than $32 \mu \mathrm{m}$ in size (fig. $3 A$ ). This finding is similar to that of $\mathrm{Li}$ and others (2005) who found 30-60 percent of the particle mass in particles smaller than $50 \mu \mathrm{m}$. The remaining two source areas, institutional roof and feeder street, had a greater presence of sand-size particles, with the majority of mass in the 63-125 and $>500-\mu \mathrm{m}$ particle fractions, respectively. For particles less than $32 \mu \mathrm{m}, 30$ to 50 percent of the mass was in particles less than $2 \mu \mathrm{m}$ for all source areas (fig. $3 B$ ).

Although normalizing the mass of each particle-size fraction as a percentage of the total mass allows for comparison of the distribution of particles amongst and between source areas, it says little about the magnitude of the mass within each particle-size fraction. Table 5 details summary statistics of concentration, in milligrams per liter, for all source areas monitored as part of this study. The feeder and arterial street study areas had the highest median values of total concentration, followed by the collector street, mixed use, parking lot, and finally, institutional roof. Despite having one of the coarsest distributions of particle size, institutional roof samples had the lowest median value of total concentration (table 5). This could be due, in part, to the presence of organic material. Organic particles generally have less mass than inorganic particles given equal size (Butler and others, 1996). The disparity between particle-size distribution and total concentration for institutional roof samples could also be an indication of the lack of source material. In a study of contaminant concentrations from source areas in Marquette, Mich., institutional roofs had the lowest concentrations of suspended solids (Steuer and others, 1997). Given the absence of fine particles, the presence of only a few large particles could result in not only a low total concentration but also a coarse distribution. Knowledge of the specific gravity of sediments in each sample would have provided additional information on the relative abundance of inorganic and organic fractions.

\section{Limitations and Suggestions for Future Research}

This study summarized particle-size distributions in stormwater runoff from selected urban source areas and land uses. Collection of water-quality samples was done by use of automated water-quality samplers with a sample intake orifice fixed near the pipe floor. In an urban environment, the energy required to transport sediment in a pipe via increased flow can change rapidly such that sediment moving as bedload can quickly be carried as suspended load, and vice versa. The location of the sampler intake can be critical, depending on the degree of sediment stratification in the storm sewer pipe. Thus, resulting concentration data and particle-size distributions resulting from a fixed-point configuration could be biased towards larger particles that tend to accumulate near the bottom of a pipe or other conveyance.

Recognition of stratification of solids in urban stormwater has led to recent improvements in sampling technology (Smith, 2002; Kayhanian and others, 2005; DeGroot and others, 2009; Selbig and Bannerman, 2011). These improvements are an attempt to collect a water-quality sample that is more representative of the entire water column rather than from a single, fixed point. Field data from one such technology, known as the Depth-Integrated Sampler Arm (DISA), show that particle-size distributions in water-quality samples collected from multiple points spaced vertically throughout the water column were generally finer than those collected near the bottom of a storm sewer (Selbig and Bannerman, 2011). If use of the DISA results in a more accurate representation of the average sediment distribution and concentration in a water column, then particle-size distributions presented as part of this study would likely require modification to mitigate the effect of sediment bias inherent with a fixed-point sampler.

\section{Summary and Conclusions}

The U.S Geological Survey, in cooperation with the Wisconsin Department of Natural Resources (WDNR) and in collaboration with the Root River Municipal Stormwater Permit Group monitored eight urban source areas representing six types of source areas in or near Madison, Wis. in an effort to improve characterization of particle-size distributions in urban stormwater by use of fixed-point sample collection methods. The types of source areas were parking lot, feeder street, collector street, arterial street, rooftop, and mixed use. This information can then be used by environmental managers and engineers when selecting the most appropriate control devices for the removal of solids from urban stormwater.

Mixed-use and parking-lot study areas had the lowest median particle sizes ( 42 and $54 \mu \mathrm{m}$, respectively), followed by the collector street study area $(70 \mu \mathrm{m})$. Both arterial street and institutional roof study areas had similar median particle 

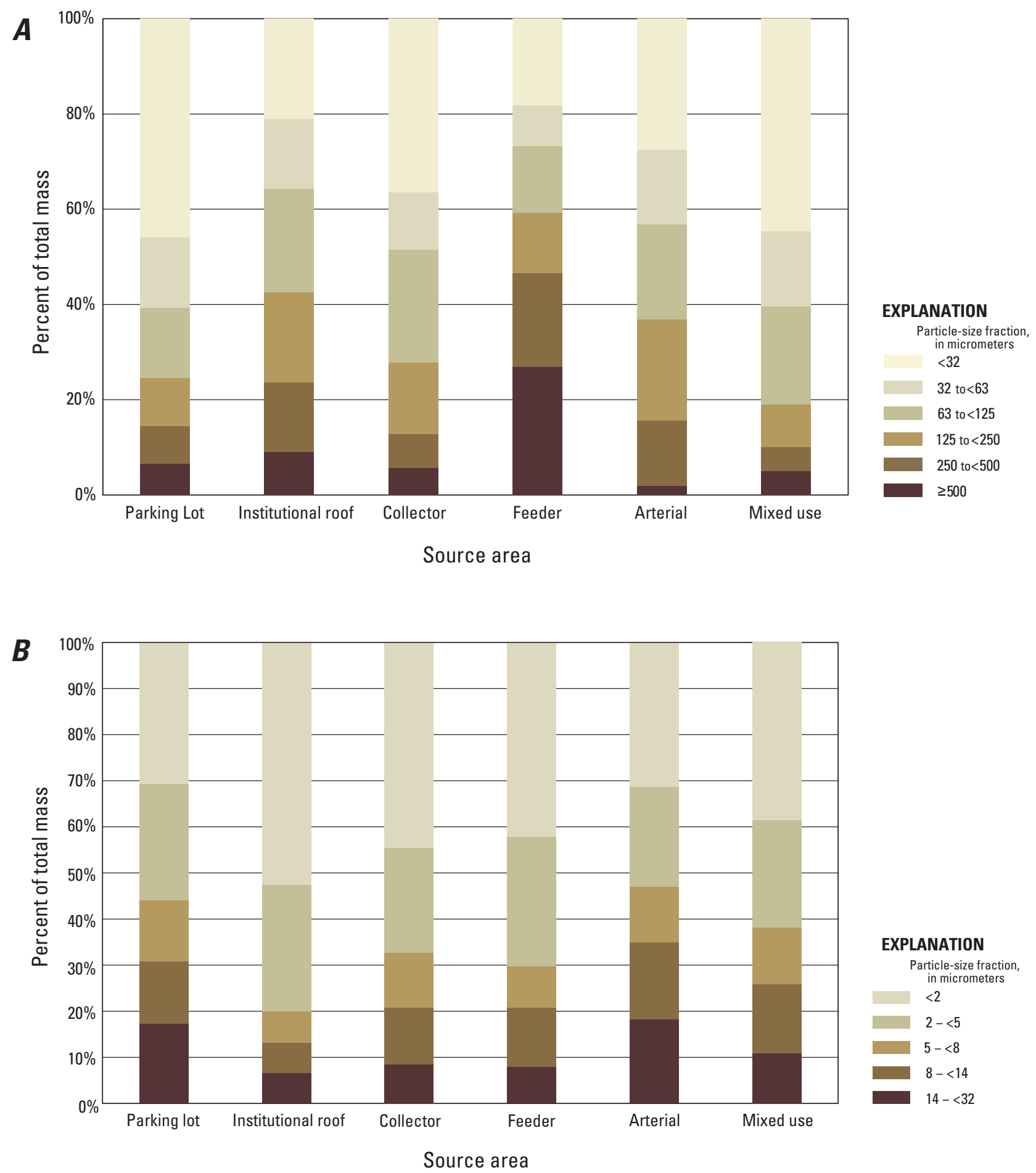

Figure 3. Median percent contribution of total mass for particles in sediment from stormwater runoff, Madison, Wis., study area. $A$, Greater than 32 micrometers. $B$, Less than 32 micrometers. 
Table 5. Summary statistics of particle-size distributions, Madison, Wis., study area, represented as a concentration. All values, with the exception of the number of observations, are in milligrams per liter.

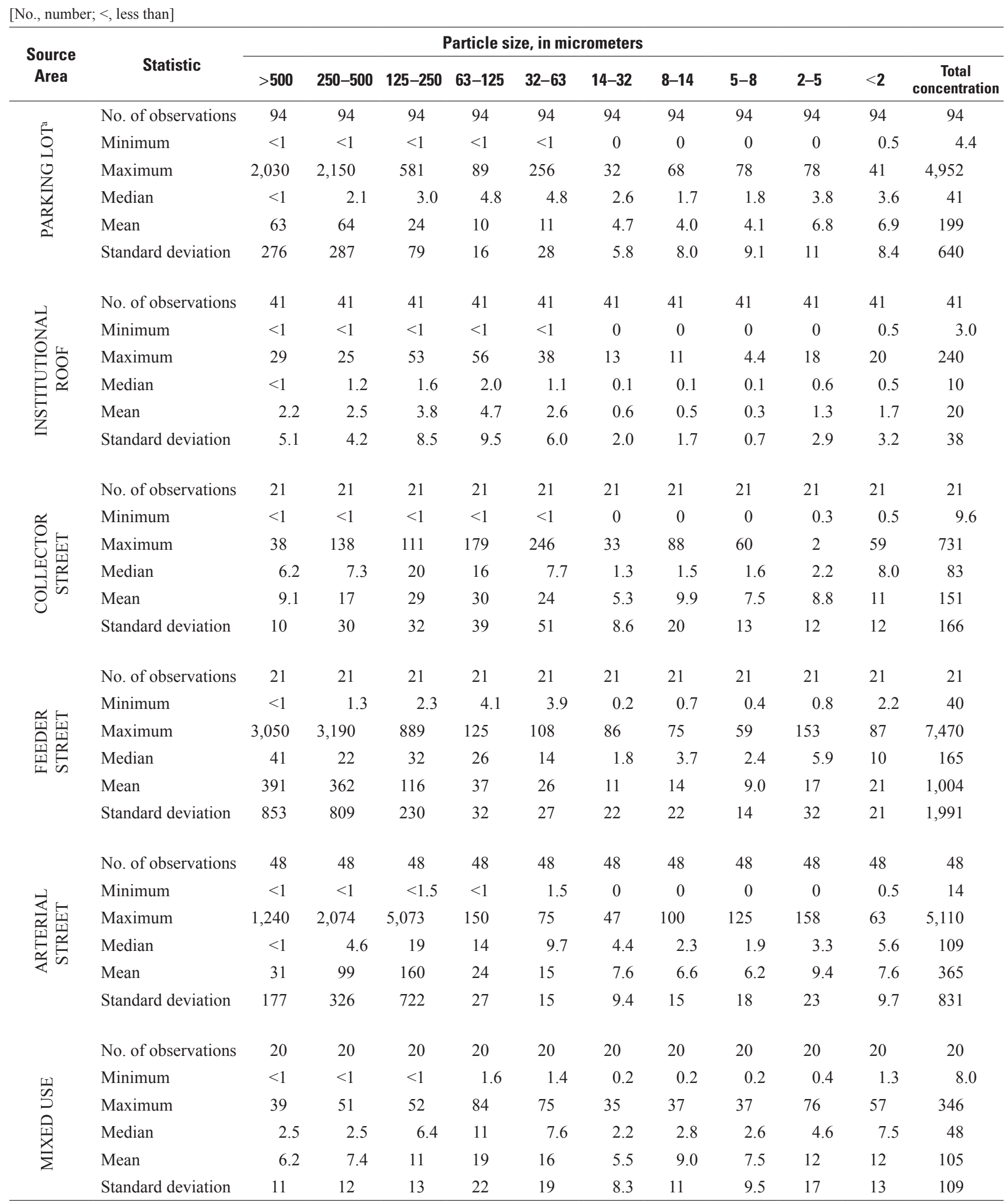


sizes of approximately $95 \mu \mathrm{m}$. Finally, the feeder street study area showed the largest median particle size of nearly $200 \mu \mathrm{m}$. Median particle sizes measured as part of this study were somewhat comparable to those reported in previous studies from similar source areas. The majority of particle mass in four out of six source areas was silt and clay particles that are less than $32 \mu \mathrm{m}$ in size.

Distributions of particles ranging from $<2$ to $>500 \mu \mathrm{m}$ were highly variable both within and between source areas. Results of this study suggest substantial variability in data can inhibit the development of a single particle-size distribution that is representative of stormwater runoff generated from a single source area or land use. Continued development of improved sample collection methods, such as the depthintegrated sample arm, may reduce variability in particle-size distributions by mitigating the effect of sediment bias inherent with a fixed-point sampler.

\section{References}

Andral, M.C., Roger, S., Montréjaud-Vignoles, M., and Herremans, L., 1999, Particle size distribution of hydrodynamic characteristics of solids matter carried by runoff from motorways: Water Environment Research, v. 71, no. 4, p. 398-407.

Anta, Jose; Peña, Enrique; Suárez, Joaquín; and Cagiao, Juan, 2006, A BMP selection process based on the granulometry of runoff solids in a separate urban catchment: Water SA, v. 32, no. 3, p. 419-428.

ASTM International, 2009, D3977-97R07, Standard test method for determining sediment concentration in water samples: Annual Book of Standards, Water and Environmental Technology, 2009, Volume 11.02.

Ball, J.E., and Abustan, I., 1995, An investigation of particle size distribution during storm events from an urban catchment, in Second International Symposium on Urban Stormwater Management, Melbourne, Australia, July 11-13, 1995, Proceedings: p. 531-535.

Bannerman, R.B., Legg, A.D., and Greb, S.R., 1996, Quality of Wisconsin stormwater, 1989-94: U.S. Geological Survey Open File Report 96-458, 26 p.

Beckman Coulter, 2010, Z Series Coulter Counter: Accessed July 30, 2010, at http://www.coulterflow.com/bciflow/ instruments 12.php\#3.

Burton, A.G., and Pitt. R., 2002, Stormwater effects handbook: A toolbox for watershed managers, scientists, and engineers, CRC Press, Boca Raton, FL, 911 p.

Butler, D., May, R.W.P., and Ackers, J.C., 1996a, Sediment transport in sewers, Part 1- Background: Proceedings of the Institution of Civil Engineers, Water and Maritime Engineering, v. 118, no. 2, p. 103-112.
Clark, S.E.; Siu, C.Y.S.; Pitt, Robert; Roenning, C.D.; and Treese, D.P., 2009, Peristaltic pump autosamplers for solids measurement in stormwater runoff: Water Environment Research, v. 81, no. 2, p. 192-200.

Corsi, S.R., Greb, S.R., Bannerman, R.B., and Pitt, R.E., 1999, Evaluation of the Multi-Chambered Treatment Train, a retrofit water-quality management device: U.S. Geological Survey Open-File Report 99-270, 24 p.

Degroot, G.P., Gulliver, J.S., and Mohseni, Omid, 2009, Accurate sampling of suspended solids: American Society of Civil Engineers Conference Proceedings 342, p. 807-813.

Drapper, Darren; Tomlinson, Rodger; and Williams, Philip, 2000, Pollutant concentrations in road runoff-Southeast Queensland case study: Journal of Environmental Engineering, v. 126 , no. 4, p. 313-320.

Driscoll, E.D., 1986, Detention and retention controls for urban stormwater, in Urbonas, Ben, and Roesner, L.A., eds., Urban runoff quality-Impact and quality enhancement technology, Proceedings of an Engineering Foundation Conference, Heinniker, N.H., June 23-27, 1986: New York, American Society of Civil Engineers, p. 145-163.

Dunn, O.J., 1964, Multiple comparisons using rank sums: Technometrics, v. 6, no. 3, p. 241-252.

Fowler, G.D.; Roseen, R.M.; Ballestero, T.P.; Guo, Qizhong; and Houle, James, 2009, Sediment monitoring bias by autosampler in comparison with whole volume sampling for parking lot runoff, in Proceedings of the World Environmental and Water Resources Congress 2009-Great Rivers, Kansas City, Mo., May 17-21, 2009: p. 1514-1522.

Furumai, H., Balmer, H., and Boller, M., 2002, Dynamic behavior of suspended pollutants and particle size distribution in highway runoff: Water Science and Technology, v. 46 , no. $11-12$, p. $413-418$.

Helsel, D.R., and Hirsch, R.M., 1992, Statistical methods in water resources: Accessed March 15 $5^{\text {th }}, 2010$ at http://pubs. usgs.gov/twri/twri4a3/.

Horwatich, J.A., Bannerman, R.T., and Pearson, Robert, in press, Highway-runoff quality, and treatment efficiencies of a hydrodynamic-settling device and a stormwater-filtration device in Milwaukee, Wisconsin: U.S. Geological Survey Open-File Report 2010-5160.

Kayhanian, M., Young, T., and Stenstrom, M., 2005, Limitation of current solids measurements in stormwater runoff: Stormwater, v. 6, no. 5, p. 40-58.

Kim, J.Y., and Sansalone, J., 2008, Particulate matter particle size distributions transported in urban runoff, in Proceedings of the World Environmental \& Water Resources Congress-Ahupua'a, Honolulu, Hawaii, May 12-16, 2008: Reston, Va., American Society of Civil Engineers, 10 p. 
Kobringer, N.P., 1984, Sources and migration of highway runoff pollutants, Volume I: Federal Highway Administration, FHWA/RD-84/057, [variously paginated].

Li, Yingxia; Lau, S.-L.; Kayhanian, Masoud; and Stenstrom, M.K., 2005, Particle size distribution in highway runoff: Journal of Environmental Engineering, v. 131, no. 9, p. $1267-1276$.

Li, Yingxia; Lau, S.-L.; Kayhanian, Masoud; and Stenstrom, M.K., 2006, Dynamic characteristics of particle size distribution in highway runoff-Implications for settling tank design: Journal of Environmental Engineering, v. 132, no. 8, p. 852-861.

Ott, R.L., and Longnecker, Michael, 2001, An introduction to statistical methods and data analysis (5th ed.): Pacific Grove, Calif., Duxbury, 1,152 p.

Sansalone, J.J., Koran, J.M., Smithson, J.A., and Buchberger, S.G., 1998, Physical characteristics of urban roadway solids transported during rain events: Journal of Environmental Engineering, v. 124 , no. 5, p. 427-440.

Selbig, W.R., and Bannerman, R.T., 2007, Evaluation of street sweeping as a stormwater-quality-management tool in three residential basins in Madison, Wisconsin: U.S. Geological Survey Scientific Investigations Report 2007-5156, 103 p.
Selbig, W.R., and Bannerman, R.T., 2011, Development of a depth-integrated sample arm (DISA) to reduce solids stratification bias in stormwater sampling: Water Environment Research, vol. 83, no. 4, pp. 347-357.

Smith, K.P., 2002, Effectiveness of three best management practices for highway-runoff quality along the Southeast Expressway, Boston, Massachusetts: U.S. Geological Survey Water-Resources Investigations Report 02-4059, 62 p.

Steuer, Jeffrey; Selbig, William; Hornewer, Nancy; and Prey, Jeffrey, 1997, Sources of contamination in an urban basin in Marquette, Michigan and an analysis of concentrations, loads, and data quality: U.S. Geological Survey WaterResources Investigations Report 97-4242, 25 p.

U.S. Environmental Protection Agency, 1982, Results of the nationwide urban runoff program: Volume II, Appendices, [variously paginated]. [Available from the National Technical Information Service (http://www.ntis.gov/) as NTIS Report PB 84-185560.]

Westerlund, Camilla, and Viklander, Maria, 2006, Particles and associated metals in road runoff during snowmelt and rainfall: Science of the Total Environment, v. 362, no. 1-3, p. 143-156. 



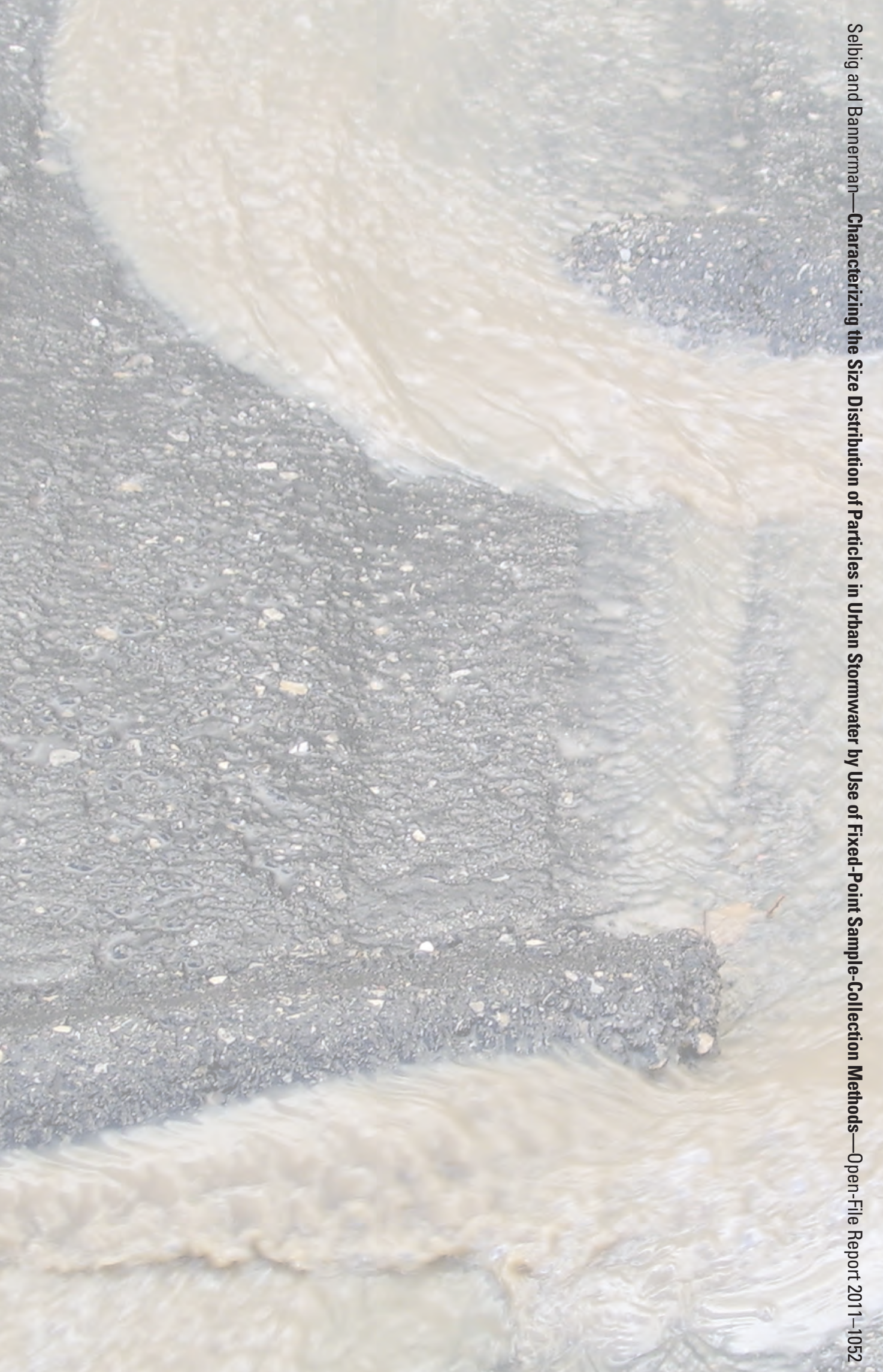

Printed on recycled paper 